DOI https://doi.org/10.18551/rjoas.2018-06.27

\title{
BEHAVIOR OF RUBBER FARM HOUSEHOLDS ON THE LABOR USAGE IN CENTRAL KALIMANTAN, INDONESIA
}

\author{
Erlina Yuni* \\ Post Graduate Program of Agriculture, Faculty of Agriculture, University of Brawijaya \\ \& Faculty of Agriculture, University of Palangka Raya, Indonesia \\ Syafrial, Koestiono Djoko, Hanani Nuhfil \\ Faculty of Agriculture, University of Brawijaya, Malang, Indonesia \\ *E-mail: erlinayuni1968@gmail.com
}

\begin{abstract}
The objectives of this research are to identify the business profile of rubber smallholders and labor in Kapuas Regency, Central Kalimantan, to examine decision pattern of farm households and influencing factors in the labor usage allocation in rubber farm households. The research location was determined purposively. The method of determining the sample used disproportionate stratified random sampling method. Total farmers as the respondents were 134 farm households. The first objective of the study was achieved using descriptive statistical analysis. The second objective was analyzed using two-stage least squares (2SLS) method. Data processing used Statistical Analysis System version 9.1 for Windows. The results of this study showed that the profile of labor usage in the households was more dominant in the rubber plantations and the allocation of labor usage was employing more productive labor in the family i.e. husbands, wives, and the working-age relative members living together in one household. Rubber price and total rubber production had a positive and significant influence on the behavior of male labor in the rubber plantations. Rubber price and a number of household members had a positive and significant influence on the behavior of female labor in the rubber plantations. However, the number of minors in the family had a negative and significant effect on the behavior of female labor in the rubber plantations.
\end{abstract}

\section{KEYWORDS}

Household economy, smallholders, male labor, female labor, labor allocation.

Developing countries generally believe that the industrial sector is able to overcome economic problems, assuming that this industrial sector can lead other economic sectors toward economic development. Similarly, in Indonesia, the industrial sector is prepared to be able to become the leading sector of other economic development sectors.

Based on data, most of the rubber plantations in 2013 were dominated by smallholders (Perkebunan Rakyat, PR) of 85.10 percent or 3.03 million hectares, Private Plantation (Perkebunan Besar Swasta, PBS) of 7.05 percent or 0.28 million hectares, and Government Plantation (Perkebunan Besar Negara, PBN) of 6.95 percent or 0.25 million hectares. Based on these data, most of the rubber plantations were community-owned plantations, causing the rubber development to be focused more on smallholders (Statistics Indonesia, 2014).

The facts show that the price of rubber in the international market not only fluctuates every year but also varies greatly. This condition impacts on the income of farm households and on the household economic behavior in the decision of the labor allocation in farm households. In the household economy, although the plantation is related to the production decision, it also indirectly influences the decision of the labor allocation in farm households. The income generated from the production activities will determine the labor allocation in farm households simultaneously. This study describes specifically the decision patterns for the labor allocation in rubber farm households and the influencing factors according to the specific location of the study. Based on the description above, the objectives of this research are (1) to identify the business profile of rubber smallholders and labor in Kapuas Regency, 
Central Kalimantan, (2) to examine decision pattern of farm households and influencing factors in the labor usage allocation in rubber farm households.

\section{METHODS OF RESEARCH}

The research was conducted by survey method at Kapuas Regency, Central Kalimantan Province, Indonesia. The research location was determined purposively. The method of determining the sample used the disproportionate stratified random sampling method. Determination of the number of respondents was done randomly (random sampling) by $30 \%$ for farmers of UPPB (Bokar Processing and Marketing Unit, Unit Pengolahan dan Pemasaran Bokar) members and $10 \%$ for farmers of non-UPPB members. Thus, 134 farm households as respondents were obtained. Data in this research included primary data and secondary data.

The first objective of the study was achieved using descriptive statistical analysis. Descriptive statistics illustrate or describe the collected data to provide useful information based on the plantation activities. The second research objective was analyzed using twostage least squares (2SLS) or maximum likelihood method. Data processing was done using SAS (Statistical Analysis System) version 9.1 for windows. Furthermore, the significance test using a statistical t-test for partial test and $F$ test statistic was employed. The coefficient of determination $\left(R^{2}\right)$ was used to know the accuracy of the model (goodness of fit).

\section{RESULTS AND DISCUSSION}

Business Profile of Rubber Smallholders. Central Kalimantan is one of the rubberproducing provinces in Indonesia, in which rubber is one of the most potential plantation commodities in the plantation sub-sector. The total area of smallholders (Perkebunan Rakyat, PR), Private Plantation (Perkebunan Besar Swasta, PBS), and Government Plantation (Perkebunan Besar Negara, PBN) in Central Kalimantan in 2013 were 269,700 ha, with potential production of 227,042 tons. In this case, the Provincial Government of Central Kalimantan focused on assisting the development of rubber smallholders because the plantations were very helpful for people's lives. Rubber smallholders not only supported society life but also created employment opportunities for the society (Statistics of Central Kalimantan, 2014).

The development pattern of rubber plantation in the research location was rubber smallholders with traditional and subsistence pattern. However, it had an important role for regional economic income, especially for rubber farm households.

The dominant clones of rubber plants planted by the farmers were local rubber clones and the recommended clones of IRR 112 and PB 260 in accordance with the specific location obtained from rubber rejuvenation assistance from the regional Department of Forestry and Plantation. The number of rubber plants in farm households varied from 333457 per hectare. Table 1 present the total production of rubber smallholders in the research area.

Based on Table 1, the rubber farm households in the three research villages encountered two seasons i.e. the dry season and the rainy season. The types of bokar (raw materials for rubber, bahan olah karet) output produced by the farmers in the research area consisted of smoked sheets, wind sheets, lumps, and slabs. However, rubber lumps were the dominant production for both farmers of UPPB and non-UPPB members since 2015. From Table 1, it can be concluded that the production of latex and lumps were dominant during the rainy season.

The Labor Usage Allocation In Farm Households. Labor is one of the capitals owned by farm households. Labor in farm household is employed to carry out various productive activities both in and outside agricultural sector including other social activities.

The labor usage in farm households employed more productive labor in the family i.e. husbands, wives, and working-age relatives living together in one household, except for 
certain activities that cannot be done by family members in the household. Table 2 presents the distribution of labor usage in farm households in the research area.

Table 1 - Total Rubber Production of Farm Households in Three Research Villages

\begin{tabular}{|c|c|c|c|c|c|c|c|}
\hline \multirow{2}{*}{ No. } & \multirow[t]{2}{*}{ Description } & \multicolumn{2}{|c|}{ Anjir Serapat Tengah } & \multicolumn{2}{|c|}{ Tamban Luar } & \multicolumn{2}{|c|}{ Sekata Bangun } \\
\hline & & UPPB & Non- UPPB & UPPB & Non- UPPB & UPPB & Non UPPB \\
\hline \multirow[t]{3}{*}{1.} & Latex: & & & & & & \\
\hline & $\begin{array}{l}\text { a. Dry season }(\mathrm{L} / \mathrm{Yr}) \\
\text { b. Rainy season }\end{array}$ & $22,101.90$ & $27,809.00$ & $23,720.80$ & $15,221.07$ & $28,751.00$ & $14,036.30$ \\
\hline & $((\mathrm{L} / \mathrm{Yr})$ & $33,152.85$ & $41,122.14$ & $35,581.20$ & $32,364.90$ & $32,619.00$ & $16,849.70$ \\
\hline \multirow[t]{3}{*}{2.} & Lump & & & & & & \\
\hline & $\begin{array}{l}\text { a. Dry season } \\
(\mathrm{Kg} / \mathrm{Yr})\end{array}$ & $16,965.10$ & $20,848.50$ & $18,339.00$ & $16,909.98$ & $19,822.00$ & $10,385.23$ \\
\hline & $\begin{array}{l}\text { b. Rainy season } \\
(\mathrm{Kg} / \mathrm{Yr})\end{array}$ & $25,447.65$ & $32,193.58$ & $27,508.90$ & $25,364.97$ & $24,321.00$ & $12,694.61$ \\
\hline
\end{tabular}

Source: Primary Data, 2017.

Table 2 - Labor Usage in Farm Households

\begin{tabular}{|c|c|c|c|c|c|}
\hline No & Activity & $\begin{array}{l}\text { UPPB } \\
(\mathrm{HOK} / \mathrm{Yr})\end{array}$ & $\begin{array}{l}\text { Percent } \\
(\%)\end{array}$ & $\begin{array}{l}\text { NON-UPPB } \\
(\mathrm{HOK} / \mathrm{Yr})\end{array}$ & $\begin{array}{l}\text { Percent } \\
(\%)\end{array}$ \\
\hline \multirow[t]{2}{*}{1.} & Rubber plantation: & & & & \\
\hline & Rubber & 191.15 & 56.73 & 182.84 & 56.06 \\
\hline \multirow[t]{5}{*}{2.} & Outside Rubber Plantation: & & & & \\
\hline & Rice field & 48.24 & 14.32 & 38.42 & 11.78 \\
\hline & Livestock & 36.31 & 10.78 & 51.06 & 15.65 \\
\hline & Other (Off and Non-Farm) & 61.26 & 18.18 & 53.84 & 16.51 \\
\hline & Total & 336.96 & 100.00 & 326.16 & 100.00 \\
\hline
\end{tabular}

Source: Primary Data, 2017.

Based on Table 2, the dominant labor usage in farm households was for rubber plantation activities which were $56.73 \%$ for farmers of UPPB members and $56.06 \%$ for farmers of non-UPPB members. The labor usage in farm households for UPPB members was 191.15 HOK (Working Day, Hari Orang Kerja) per year, consisting of 149.34 HOK of male labor and 71.20 HOK of female labor, while for non-UPPB member were $182.84 \mathrm{HOK}$ per year, consisting of $141.31 \mathrm{HOK}$ of male labor and $61.44 \mathrm{HOK}$ of female labor.

The Behavior of Labor Usage in the Rubber Plantations. The labor usage in the research location consisted of male and female labor. This term was used because, in the research location, the labors not only consisted of the husbands and wives but also family labors in kinship relationships living in one household such as adult siblings and nephews. In this study, farm households did not involve children labor in the rubber plantations due to the increasing household's awareness of the importance of education, causing the farmers' children to pursue their education inside and outside the sub-district or regency. This was in line with the government program to improve the education level in the society, especially people in the rural area.

The behavior of the labor usage was commonly from the farm households because this research only analyzed the farmers who directly owned and managed the rubber plantations. In addition, the farmers of UPPB members were mostly the owner of the rubber plantations. Table 3 presents the parameter estimation results of labor usage equation model in the rubber plantations.

Based on Table 3, the result of equation analysis on male labor behavior (TKPKR) in the rubber plantations obtained the coefficient of determination (R2) of 0.56600 which meant that 56.600 percent of male labor variable was able to be explained by variables in the model, while the rest was more influenced by other variables outside the model. The result of $F$ test analysis was 32.78 with less than one percent significance of error rate. The result of autocorrelation test with Durbin Watson (DW) criterion test was 1.854083. The value was still between the determination of the value of 1.55-2.46 (Misbahuddin and Hasan, 2013). It can 
be concluded that the structural equation had no indication of autocorrelation between variables.

Table 3 - Parameter Estimation Results of Labor Usage Equation Model In the Rubber Plantations

\begin{tabular}{lllll}
\hline Dependent Variables & Explanatory Variables & Parameter Value & t-count & Error Rate \\
\hline TKPKR & Intercept & 71.69845 & 2.99 & 0.0002 \\
& HBR & 0.00794 & 2.72 & 0.0228 \\
& LLK & 15.45877 & 0.59 & 0.5576 \\
& TPBR & 0.045816 & 1.88 & 0.0622 \\
& ERT & $-512 \mathrm{E}-7$ & -030 & 0.7655 \\
\cline { 2 - 5 } & $\mathrm{R}^{2}$ & 0.56600 & $\mathrm{Pr}>\mathrm{F}$ & $<.0001$ \\
& F-Count & 32.78 & $\mathrm{DW}$ & 1.854083 \\
\hline TKWKR & Intercept & 19.75217 & 0.76 & 0.4459 \\
& HBR & 0.003795 & 2.80 & 0.0442 \\
& LLK & -4.98240 & -0.78 & 0.4392 \\
& ERT & $-1.41 \mathrm{E}-6$ & -0.68 & 0.4969 \\
& JART & 8.794727 & 2.11 & 0.0370 \\
& JABU & -19.6025 & -4.82 & $<.0001$ \\
\cline { 2 - 5 } & $\mathrm{R}^{2}$ & 0.62505 & $\mathrm{Pr}>\mathrm{F}$ & $<.0001$ \\
& F-Count & 54.19 & $\mathrm{DW}$ & 2.079347 \\
\hline
\end{tabular}

The result of partial analysis with a t-test showed that the variable of bokar price had a positive and significant effect on the male labor usage with five percent error rate. A positive sign indicated that when the price of bokar was high, the farmers increased the number and productive working time of male labor usage in the rubber plantations. This behavior was in line with the conditions or symptoms occurring at the research location, in which increasing price of rubber caused more dominant male labor in the rubber plantations. On the other hand, the declining rubber prices caused a reduction in male labor usage. Female labor was the one working in rubber tapping process. Accordingly, the total bokar production variable had a positive and significant effect on male labor with 10 percent error rate. Therefore, the increasing total production of bokar caused the increasing male labor usage.

The result of equation analysis on female labor behavior (TKWKR) in the rubber plantations obtained the coefficient of determination (R2) of 0.62505 which meant that 62.505 percent of female labor variable was able to be explained by variables in the model, while the rest was more influenced by other variables outside the model. The result of $F$ test analysis was 54.19 with less than one percent significance of error rate. It meant that all explanatory variables simultaneously affected female labor in the rubber plantations. The result of autocorrelation test with Durbin Watson (DW) criterion test was 2.079347. The value was still between the determination of the value of 1.55-2.46 (Misbahuddin and Hasan, 2013). It can be concluded that the structural equation had no indication of autocorrelation between variables.

The result of partial analysis with a t-test showed that the variable of bokar price (harga bokar, HBR) had a positive and significant effect on the female labor usage with five percent error rate. A positive sign indicated that when the price of bokar was high, the farmers increased the number and productive working time of female labor usage as an effort to increase the rubber farm household economy.

The number of family members (jumlah anggota rumahtangga, JART) had a positive and significant impact with five percent error rate. It meant that the more productive members of households, the more available labor in households useful for rubber production activities.

At the research locations, some working wives had minors. The t-test result on the variable of the number of minors (jumlah anak di bawah umur, JABU) was negative and significant with less than one percent error rate. The parameter value was -19.6025 significant with less than one percent error rate. It meant that if the number of minors increased by one child, the allocation of working time for female labor with minors reduced by 19.6025 HKP per year in rubber production activity. 


\section{CONCLUSION AND RECOMMENDATIONS}

The profile of labor usage in the households was more dominant in the rubber plantations. The environmental condition of rubber farmers greatly influenced household economic behavior especially in the decision of the labor allocation in farm households. In the household economy, although the plantation is related to the production decision, it also indirectly influences the decision of the labor allocation in farm households. The labor usage involved male and female labor. This behavior was in line with the conditions or symptoms occurring at the research location, in which increasing price of rubber caused more dominant male labor in the rubber plantation. On the other hand, the declining rubber prices caused a reduction in male labor usage

Rubber price and total rubber production had a positive and significant influence on the behavior of male labor in the rubber plantations. Rubber price and a number of household members had a positive and significant influence on the behavior of female labor in the rubber plantations. However, the number of minors in the family had a negative and significant effect on the behavior of female labor in the rubber plantations.

For the policymakers, in order to increase the allocation of labor usage in the rubber plantations, it is necessary to provide assistance with more intensive counseling in the plantation management. It is due to the rubber plantations are the main income source for the farmers and a support for economic needs of rubber farm households.

For the farmers, it is expected that the allocation of male and female labor usage can be further improved and balanced with the improvement of rubber quality. Thus, the farmers can focus more on rubber plantation management in order to increase the household income.

\section{REFERENCES}

1. Badan Litbang Pertanian, 2013. Prospek dan Arah Pengembangan Agribisnis Karet. Jakarta.

2. Badan Pusat Statistik, 2014. Kalimantan Tengah Dalam Angka 2013. Provinsi Kalimantan Tengah.

3. Badan Litbang Pertanian, 2013. Prospek dan Arah Pengembangan Agribisnis Karet. Jakarta.

4. Badan Pusat Statistik, 2016. Provinsi Kalimantan Tengah Dalam Angka 2016. Provinsi Kalimantan Tengah.

5. Badan Pusat Statistik, 2016. Kabupaten Kapuas Dalam Angka 2016. Provinsi Kalimantan Tengah.

6. Becker, G.S. 1965. The Economic Approach to Human Behavior. The University of Chicago Press. Chicago.

7. Budiman A., 2000. The Future of Natural Rubber Production and Quality in Indonesia. http://digilib.unila.ac.id. diakses 10-11-2014.

8. Debertin, D. L. 1986. Agriculture Production Economics. Mac Millan Publishing Company. New York.

9. Direktorat Jenderal Perkebunan, 2017. Karet 2015-2017. Statistik Perkebunan Indonesia.

10. Ditjen Pengolahan dan Pemasaran Hasil Pertanian, 2011. Pedoman Penerapan Sistem Jaminan Mutu Bokar. Kementerian Pertanian. Jakarta.

11. Effiong J.B., and Effiong G. B., 2014. Adoption of Improved Rubber Production Technologies By Farmers In Akwa Ibom State, Nigeria. Global Journal of Agricultural Sciences. ISSN 1596-2903. Vol.14, 2015:37-44.

12. Ellis, F., 1989. Peasant Economics, Farm Households and Agrarian Development. Cambride University Press. New York.

13. Ethridge Don, 1995. Research Methodology in Applied Economics (And Conducting Economic Research). lowa State University Press. Pp: 101-113

14. Gardner, B. L., and Gordon C., Rausser, 2001. Handbook of Agricultural Economics. Elsevier. Amsterdam-London-New York-Oxford-Paris-Shannon-Tokyo. 
15. Gujarati, D., 2012. Dasar-dasar Ekonometrika. Buku 2. Penerbit Salemba Empat.

16. Hendratno, S., 2006. Kompromi Kooperatif dan Alokasi Sumberdaya Internal Rumahtangga Petani Karet di Sumatera Selatan. Disertasi. Sekolah Pascasarjana. Institut Pertanian Bogor. Bogor.

17. Husin Laila, 2012. The Rubber Farm Household's Behavior on Economic Activities to Achieve Family Food Security. Departement of Agribusiness, Sriwijaya University, South Sumatera, Indonesia. Journal Elsevier ICAAA 2012: July 23-24, 2012, Singapore.

18. Husin L., dan Sari D., 2011. Perilaku Ekonomi Rumahtangga Petani Karet di Prabumulih dalam Alokasi Tenaga Kerja, Produksi dan Konsumsi. Fakultas Pertanian Universitas Sriwijaya. Sumatera Selatan.

19. International Rubber Study Group (2007). The Rubber Industry of Indonesia: Review and Prospect to 2020. International Rubber Study Group.

20. Johnson Glenn L., 1986. Research Methodology For Economists (Philosophy and Practice). Macmillan Publishing Company. New York.

21. Leki S., 2016. Model Ekonomi Rumahtangga Pertanian Campuran Untuk mencapai Ketahanan Pangan (Di Wilayah Timor Barat Provinsi Nusa Tenggara Timur). Disertasi Doktor. Program Pascasarjana Fakultas Pertanian Universitas Brawijaya, Malang.

22. Ling Hsu Wan, 1997. Technology Adoption, Risk, And Intrafamily Time Allocation : An Application of The Agricultural Household Model. Thesis. Doctor of Philosophy. Agricultural Economics. The Pennsylvania State University. Departement of Agricultural Economics and Rural Sociologi.

23. Misbahuddin dan Hasan, I., 2013. Analisis Data Penelitian dengan Statistik. Edisi ke-2. Bumi Aksara. Jakarta. Hal.71-166; 258-267.

24. Makki, M. F., 2014. Perilaku Ekonomi Rumahtangga Petani Tanaman Padi di Lahan Rawa Lebak Kabupaten Hulu Sungai Utara Kalimantan Selatan. Disertasi Doktor. Program Pascasarjana Fakultas Pertanian Universitas Brawijaya, Malang.

25. Maspanger, D. 2004. Dampak Penerapan Produksi Bersih Industri Crumb Rubber Pada Peningkatan Pasar Global. Disampaikan pada Seminar/Temu Usaha Sosialisasi Produksi Bersih Industri Crumb Rubber. Pekan Baru, 6 Oktober 2004.

26. Mubyarto, 1991. Karet, Kajian Sosial-Ekonomi. Penerbit Aditya Media. Yogyakarta.

27. Nazir, Moh., 2013. Metode Penelitian. Ghalia Indonesia. Jakarta.

28. Purwanti Pudji, 2010. Model Ekonomi Rumah Tangga Nelayan Skala Kecil Dalam Mencapai Ketahanan Pangan. Universitas Brawijaya Press. Malang. Indonesia.

29. Pindyck, R. S. and D. L. Rubinfeld, 1991. Econometric Models and Economic Forecasts. Second Edition. McGraw-Hill Book Co. Singapore.

30. Setyamidjaja D., 1993. Karet, Budidaya dan Pengolahan. Penerbit Kanisius. Yogyakarta.

31. Singh, 1986. The Basic Model: Theory, Empirical Results and Policy Concluttions; Agricultural Household Models: Extentions, Applications and Policy. The John Hopkins University Press, Baltimore.

32. Singh, I. L., Squire and J. Strauss, 1986. The Basic Model: Theory, Empirical Result and Policy Conclutions. In: Singh, I, L. Strauss (Eds). Agricultural Household Model: Extensions, Applications and Policy. The Johns Hopkins University Press, Baltimore and London.

33. Sitepu K. Rasidin., dan Sinaga M. Bonar., 2006. Aplikasi Model Ekonometrika: Estimasi, Simulasi dan Peramalan Menggunakan SAS. Program Studi IImu Ekonomi Pertanian. Sekolah Pascasarjana. Institut Pertanian Bogor. Bogor.

34. Sugiyono, 2015. Metode Penelitian Kuantitatif Kualitatif dan R \& D. Penerbit Alfabeta. Bandung.

35. Summer, D. A., 1982. The Off-Farm Labor Supply of Farmers. American Journal of Agricultural Economics. Vol. 64, pp. 499-509.

36. Utomo, T.P., A.M. Fauzi, T. Tedja, M. Romli, A. Aman, dan S. Honggokusumo. 2008. Kajian Perbaikan Agroindustri Karet Remah Menggunakan Interpretative Structural Modelling. Prosiding Seminar Nasional Sains dan Teknologi-II 2008. Bandar Lampung, 17-18 November 2008.

37. Widarjono Agus., 2007. Ekonometrika: Teori dan Aplikasi. Penerbit Ekonisia. Yogyakarta. 